\title{
Ethical, Environmental, Social and Governance-oriented Investments June 2017
}

\author{
Julia M. Puaschunder \\ Columbia University \\ Graduate School of Arts and Sciences
}

\begin{abstract}
In the aftermath of the 2008/9 World Great Recession, ethical investing blossomed as opportunity to imbue trust in the economy. The crisis aftermath offered invaluable opportunities to redefine social investment to strengthen a more sustained, inclusive and equitable society. The 2015 incepted Sustainable Development Goals spearheaded the idea of financing societal advancement. Ethical, Environmental, Social and Governance-oriented Investments are key to sustainable prosperity. In the wake of stakeholder activism and based on intrinsic socio-psychological motives, ethics, environment, social and governance roots in finance hold untapped opportunities of sustainable prosperity in the finance world and in the implementation of sustainable prosperity.
\end{abstract}

\section{INTRODUCTION}

In the aftermath of the 2008/9 World Great Recession, ethical investing blossomed as opportunity to imbue trust in the economy (Puaschunder, 2016c). The crisis aftermath offered invaluable opportunities to redefine social investment to strengthen a more sustained, inclusive and equitable society. The 2015 incepted Sustainable Development Goals spearheaded the idea of financing societal advancement (Puaschunder, 2017c).

Ethical, Environmental, Social and Governance-oriented Investments are key to sustainable prosperity. In the wake of stakeholder activism and based on intrinsic socio-psychological motives, ethics, environment, social and governance roots in finance hold untapped opportunities of sustainable prosperity in the finance world and in the implementation of sustainable prosperity (Puaschunder, 2013, 2017b).

As an investment philosophy that combines profit maximization with social endeavors; SRI integrates social, environmental and financial aspects in investments (Livesey, 2002; Matten \& Crane, 2005; Puaschunder, 2013; 2017b; Wolff, 2002). Socially conscientious investors pursue economic and social value maximization alike in social screenings, shareholder advocacy and community investing (Renneboog, Horst \& Zhang, 2007; Schueth, 2003; Puaschunder, 2015c). Thereby SRI embraces a variety of stakeholders comprising economic, organizational and societal constituents.

In the age of climate change raising economic growth versus environmental protection predicaments, the time is ripe to pay attention to the history of allocating finance towards environmental, social and governance causes in order to retrieve success factors to align economic with greater societal goals. Studying the history of SRI and international practice of Financial Social Responsibility helps draw conclusions about the future potential of SRI in the era of global warming. Reflecting financial social conscientiousness through a historic lens allows deriving natural Financial Social Responsibility triggers and SRI success factors in order to aid the ongoing adoption of SRI around the globe. 
History does not repeat itself but we can learn from it in current times of economic and environmental governance turmoil. Originating from religious and moral considerations, Socially Responsible Investment (SRI) evolved in the wake of sociopolitical deficiencies, legislative compulsion and corporate social responsibility. As part of human nature, social responsibility guides corporate activities and financial considerations. In the global rise of financial social conscientiousness, differing national legislations and regulatory traditions have led to various SRI practices, which are harmonized by the United Nations (UN) (Puaschunder, 2010). The societal demand for imbuing social responsibility in economic markets has risen steadily in recent decades due to globalization and socio-political trends. In the aftermath of the 2008/09 World Financial Crisis, the call for social responsibility in financial markets climaxed. The announcement of the recapitalization of the banking system in October 2008 created a need for reconsideration of social responsibility in a newly defined finance world. Novel sources of economic tension make ethical, environmental, social and governanceoriented investments appear as more stable investment option to deal with global imbalances and other structural problems.

The historic emergence of Financial Social Responsibility shows social conscientiousness to peak in the wake of socio-economic deficiencies, humanitarian downfalls and legislative compulsion, which provides a convincing case for the appreciation of the current crisis' role to ingraining ethicality in economic markets.

Social and ethical considerations in financial markets have a long tradition stemming from religious roots. The early beginnings of modern SRI are attributed to social responsibility concerns in the face of social, environmental and political deficiencies and humanitarian crises (Puaschunder, 2016c; Williams, 2005). In the post-World War II era, first financial social considerations ideas sparkled in the wake of legislative compulsion, information disclosure and governmental policies encouraging trustees' social responsibility (Solomon, Solomon \& Norton, 2002; Sparkes \& Cowton, 2004). During the 1960s stakeholder pressure and antiVietnam War movements alerted institutional investors to sell napalm-producing Dow Chemical shares (Biller, 2007). Civil rights campaigns and social justice initiatives opposed college endowments funding warfare. Minority empowerment, consumer rights activism and environmentalism sensitized for financial social conscientiousness (Renneboog et al., 2007; Sparkes, 2002). Since 1969 the Council on Economic Priorities rated corporate social and environmental performance. After a Yale conference introduced Financial Social Responsibility, universities established committees to advise trustees on social investment. Subsequently Methodist clergy created the PAX World Fund aimed at divestiture from Vietnam War supporters (Broadhurst, Watson \& Marshall, 2003; Renneboog et al., 2007). The Dreyfus Third Century Fund opened the following year to avoid 'sin stocks' and improve social labor standards. By the mid-1970s, a significant number of governments had enacted shareholder rights to address corporate activities that caused 'social injury' and many universities established committees to advise trustees on SRI and shareholder rights. The Investor Responsibility Research Center (IRRC) and the Interfaith Center on Corporate Responsibility (ICCR) were launched to promote shareholder advocacy and proxy resolutions around the same time (Social Investment Forum Report, 2006). In 1972 activists criticized Harvard University for owning shares in petroleum corporations. Political divestiture became firstly discussed in the case of the Angolan repressive government (Alperson, Tepper-Marlin, Schorsch \& Wil, 1991). In 1976 Reverend Leon Sullivan - a civil rights activist and director of General Motors - developed the Sullivan Principles to foster equal remuneration and workplace opportunities to empower minorities (Voorhes, 1999). During the 1980s political divestiture was practiced by US universities, investors, churches, city and state governments as 
a means to dismantle the South African Apartheid regime featuring racial segregation and economic discrimination against non-European groups (Schueth, 2003; Soros, 2008). Environmental catastrophes in Chernobyl, Bhopal and the Exxon Valdez oil spill perpetuated shareholder activism. With the desire to set standards for corporate social engagement and environmentally conscientious conduct, social investors started positive screenings in the beginning of the 1990s. The Domini 400 Social Index institutionalized ratings of Standard \& Poor's 500 (S\&P) corporations. The microfinance revolution and the co-operative banking system further galvanized the idea of SRI (Brenner, 2001). The 2008/09 World Financial Crisis has put a novel perspective to the promotion of Financial Social Responsibility. Above the advancement of global governance goals through the engagement of financial markets, the idea of SRI began to offer the prospect of market stability and means to imbue trust in the post 2008/09 World Economy (Puaschunder, 2016c).

Within recent decades Financial Social Responsibility boomed in the wake of globalization and political trends. An unprecedented interconnectivity of globalized financial markets strengthened the societal role of financial institutions. Political libertarianism implicitly shifted social responsibility onto the private sector. Deregulated liberalization attributed a rising share of global governance onto financial markets. Financial social considerations leveraged into an implicit fiduciary responsibility (Solomon et al., 2002; Sparkes \& Cowton, 2004). As social global governance increasingly entered financial markets since the turn of the millennium, a growing proportion of investment firms and governmental agencies around the world adopted a more socially conscientious investment philosophy (Knoll, 2008; McCann, Solomon \& Solomon, 2003; Sparkes, 2002). Information disclosure on corporate social conduct in combination with benchmarking of corporate social engagement and governmental encouragement of trustees' social conscientiousness propelled SRI. Institutional investors concurrently used their clout to influence corporate conduct and actively demanded corporate governance reforms to act on societal and intergenerational concerns (Puaschunder, 2015b, 2017e).

The advanced consideration of Financial Social Responsibility by major institutional investors matured SRI from a niche market option that was offered by specialist retailers to a more mainstreamed asset allocation style (Mathieu, 2000; Sparkes \& Cowton, 2004). SRI reached unprecedented diversity featuring a wide range of social engagement possibilities (Rosen, Sandler \& Shani, 1991). As SRI gained in prominence and broadened in size, scale and scope; practitioners and academics started documenting state-of-the-art Financial Social Responsibility practices. Business professionals reported and analysts monitored social, ethical and environmental corporate performance. Social and environmental stock exchange rating agencies and certifications measured SRI impacts. Today the range of shareholder engagement possibilities is more sophisticated than ever and trends forecast a further maturation of SRI from a niche segment solution into a mainstream market feature. In the international arena, various SRI practices emerged concurrently as national rules and legal jurisdictions shape corporate and financial social conduct (Steurer, 2010). Legal boundaries guide financial considerations and institutional frameworks predestine Financial Social Responsibility practices (Reinhardt et al., 2008).

The beginning of the 21st century has proven to be a time of novel opportunities and unknown risks for corporate innovation, economic stability and human progress. With current trends predicting a polarization of either globalization or protectionism trends that play out in heightened environmental concerns in the light of climate change; global governance on sustainable finance must create a stable, competitive market economy whilst ensuring sustainable social development. Given this background, corporate and financial actors face 
unfamiliar risks and unprecedented social responsibility demands (World Bank, 2015). In the light of these challenges, future research must address social responsibility as a world-wide societal phenomenon that is construed by human constituents and exogenous influences (World Development Report, 2015).

Socially conscientious asset allocation styles add to expected yield and volatility of securities social, environmental and institutional considerations (Puaschunder, 2017c). Altruism, need for innovation and entrepreneurial zest alongside utility derived from social status enhancement prospects and transparency may steer investors' social conscientiousness. Selfenhancement and social expression of future-oriented SRI options may supplement profit maximization goals. SRI can be seen as crises-robust, long-term sustainable market options that are extraordinary stable diversification means during external market shocks. Focus on ethics, environment, social and governmental concerns is a crisis stable market option that alongside helps improving financial markets and economic market systems (Puaschunder, 2017b).

In the eye of globalized markets and international societal challenges, such as foremost climate change; international organizations currently harmonize differing SRI practices throughout the international arena. International organizations define SRI standards and guideline the Financial Social Responsibility implementation from a global governance perspective. A more harmonious picture of concerted Financial Social Responsibility is meant to foster financial markets' global governance impetus in the pursuit of societal goals (Hong, Li \& Xu, 2016). Transnational entities play a pivotal role in institutionally supporting Financial Social Responsibility and streamlining disparate SRI practices throughout the world. The United Nations (UN) leads the international public administration of Financial Social Responsibility in the United Nations Global Compact's (UNGC) Board launched 'Principles for Responsible Investment' (PRI).

Future multi-stakeholder analyses may attribute the newly-defined role of public and private constituents in social contributions and search for the optimum balance of deregulated market systems and governmental control in providing Financial Social Responsibility. Capturing realmarket social responsibility phenomena could thereby not only help finding well-tempered public-private partnership networks to support modern market economies. Oversight accountability could also present information on corporate and financial social conduct that will lead academics, technocrats and practitioners to reflect deeper about responsibility within market systems and rethink their roles in backing socially-favorable market structures.

Additional general investigations of the perception of SRI in the age of climate change could determine in what way the warming earth has changed the financial community's view of economic markets' social responsibility obligations. Once-in-a-century-available information on the social representations of financial social conscientiousness in the post-COP21 agreement era should be reaped as a unique source on the economic versus ecologic responsibility predicament of global governance. Studying investors' cognition on SRI in this unique point in time also provides an innovative snapshot of how to ingrain ethicality in competitive market systems.

Innovatively coupling individual decision making research findings' with insights on external influences on social responsibility promises to help managing financial market social responsibility risks with respect for sustainable development for society. While microbehavioral economists may in particular unravel human socially responsible cognition in the 
search for human-imbued ethicality nudges; macro-economists may explain how individual social responsibility can shape collective market outcomes in harmony with the greater societal common goods endeavors.

Science may attribute how a globalizing world moderates individuals' decision making on social responsibility in order to avert predictable surprises of future global crises. Future research on the fallibility of human decision makers and external, global influences on social responsibility may help deriving recommendations on how to steer socially conscientious behavioral patterns in modern economic markets. For instance, as a fortification of political divestiture advocating for conscientiousness of financial market transactions; societallyharmful short-sighted day-trading in externally-shocked crises markets could be considered for ethical scrutiny (Puaschunder, 2016d).

An extraordinarily interesting application of environmental investment appears in the light of global warming. Climate change accounts for one of the most pressing problems in the age of globalization as for exacerbating more complex risks than ever before (Puaschunder, 2011). As never before in history since the birth of the earth, there is an environmental sensitivity to economic growth (The World Economic Forum Report, 2015). Today climate control needs have reached unprecedented momentum. Climate change has leveraged intergenerational equity as contemporary challenge of modern democracy and temporal justice an ethical obligation for the sake of sustainable development (Puaschunder, 2017a, d).

In the current post-COP21 Paris agreement climate change mitigation and adaptation efforts, the financialization of the ambitious goals has leveraged into an internationally challenging demand. While scientists call for stabilizing climate and regulators structure climate change mitigation and adaptation efforts around the globe; economists are concerned with finding proper and fair financing mechanisms. What is blatantly lacking are sophisticated mathematically-well-calibrated models in finding the optimal solution when to phase in what climate mitigation strategy. Most recent political predicaments arise whether politicians have a responsibility to their direct voting populace, the contemporary world population or even future generations. Problematic appears that curbing carbon emissions was traditionally related to lowering economic activity and therefore lowers economic growth. Current generations thereby are seen to sacrifice for future generations' uncertain living conditions. But not does an economic growth versus sustainable development predicament arises, paying today for climate change mitigation and adaptation also raises intergenerational equity considerations and implementation feasibility questions. As an innovative approach to raise interest in climate mitigation and adaptation financialization and the overcome humane decision making inconsistency over time but also curb myopia in light of future uncertainty and individually limited life spans, green bonds have recently been proposed to steer action on climate stability as for offering a favorable intertemporally balanced, economically dominant solution.

In an overlapping-generations framework, Sachs (2014) solves the climate change mitigation economic growth versus sustainable development predicament that seems to pit today's against future generations. Sachs (2014) thereby proposes that the current generation mitigates climate change financed through bonds to remain financially as well off as without mitigation while improving environmental well-being of future generations through ensured climate stability. Bonds are traditionally issued by companies, municipalities, states and sovereign governments to raise money and finance a variety of future-oriented long-term projects and activities (Puaschunder, 2016c). As debt investment in which investors loan money to an entity, bonds allow to borrow funds from the populace for a defined period of 
time at a variable or fixed interest rate. A green bonds solution is introduced as real-world relevant means to tap into the worldwide USD 80 trillion bond market in order to fund the incentives to a transition to a sustainable path (Puaschunder, 2016c, 2017a, c; Sachs, 2014; World Bank, 2015). Historically, bonds have been used to fund large-scale investment projects ranging from infrastructure development to wars. The funds raised by bonds could be used in order to offset for the industry losses incurred in the wake of climate change. At the same time, funds available would also allow to incentivize industries to transition into green energy. For example, if the bonds fund corporations and allow tax breaks for sectors that transition to renewable energy, the previous price-cutting race to the bottom in competitive market situations could be transformed to a race to the top. Firms would ideally then compete over positive market incentives, such as tax breaks and direct funds for a clean production. It would become economically efficient to turn to climate change mitigation and adaptation.

In combination with carbon tax, sharing the costs of climate change aversion between and across generations appears as important strategy to instigate immediate climate change mitigation through incentivizing emission reduction and provide adaptation. In an innovative tax-and-transfer-strategy, climate stability could be financed immediately by the current generation, while future generations repay the bonds through taxation. Overall this turns climate change burden sharing into a Pareto improving option over time (Marron \& Morris, 2016; Puaschunder, 2016b).

The clear advantages of this approach is the simple Pareto-improving economically dominant strategy backed by powerful examples in history of ideologies funded by bonds. In a lossaverse world, the bonds solution appears to avoid disincentives of curbing economic growth. Public servants and global governance experts embrace this solution as a fairly easily implementable solution that avoids scaring the populace by economic drawbacks or fear over a depleting favorable climate. The historic successes of bonds-financed ideologically-driven projects let this solution appears as the most favorable to embrace the many stakeholders climate stabilization will demand (Puaschunder, forthcoming b). Most novel developments most innovatively determine climate justice around the globe in considering the gains and losses of a warming globe (Puaschunder, 2017a, d). Shedding unprecedented light onto the gains for a warming earth (e.g., if considering GDP growth prospects in cooler parts of the world) offers unknown opportunities for raising funds for climate change mitigation and adaptation. In addition, by calculating the unequal global warming gains and losses distribution, ethical imperatives for climate justice naturally follow (Puaschunder, 2017a, d).

Recommendations target at ingraining social responsibility in economic systems by global governance, multi-stakeholder management and governmental assistance of the implementation and administration of ethics of environmental, social and governance-oriented investments (Puaschunder, 2015a). In the future, governmental assistance should contribute to the implementation and administration of SRI with attention to private sector and civil demands. As the basis for stakeholder engagement and monitoring, transparency and accountability are key for advancing corporate and financial social market behavior. The newly emerging sustainable finance phenomena open avenues for future research with respect for current social responsibility trends. Transparency and accountability are key for monitoring financial social responsibility. As for the ongoing adaptation and adoption of SRI, future research must attribute the newly defined role of social responsibility in the interplay of public and private actors given concurrent sustainable development trends (Marron \& Morris, 2016; Puaschunder \& Schwarz, 2012; Puaschunder, 2017a). 
All these endeavors are aimed at fostering Financial Social Responsibility as a future guarantor of economic stability and sustainable social progress throughout the world. As an overarching goal, helping to leverage SRI into a more mainstream economic trend by fostering financial social conscientiousness as an implicit financial crises mitigation means can aid financial market stability. This piece hopefully will contribute to a future rise of social responsibility in our currently globalizing, economically-transforming and environmentally-fragile world, in which we should feel responsible.

\section{References}

Alperson, M., Tepper-Marlin, A. T., Schorsch, J. \& Wil, R. (1991). The better world investment guide: One hundred companies whose policies you should know about before you invest your money. From the Council on Economic Priorities. Prentice Hall: New York.

Biller, A. (2007). Socially responsible investing now part of the landscape. Benefits \& Compensation Digest, 44, 12. Brenner, R. (2001). The force of finance: Triumph of the capital markets. New York: Texere.

Broadhurst, D., Watson, J. \& Marshall, J. (2003). Ethical and socially responsible investment. A reference guide for researchers. München: Saur.

Hong, H.G., Li, F.W. \& Xu, J. (2016). Climate risk and market efficiency. Cambridge, MA: National Bureau of Economics Research Paper.

Knoll, M. S. (2008). Socially responsible investment and modern financial markets. Unpublished working paper, University of Pennsylvania Law School.

Livesey, S. (2002). The discourse of the middle ground: Citizen Shell commits to sustainable development. Management Communication Quarterly, 15, 313-349.

Mathieu, E. (2000). Response of UK pension funds to the SRI disclosure regulation. London: UK Social Investment Forum.

Matten, D. \& Crane, A. (2005). Corporate citizenship: Toward an extended theoretical conceptualization. Academy of Management Review, 30, 166-179.

Marron, D.B. \& Morris, A.C., 2016. How to use carbon tax revenues. Washington, D.C.: Tax Policy Center Urban Institute \& Brookings Institution.

McCann, L., Solomon, A. \& Solomon, J. F. (2003). Explaining the growth in U.K. socially responsible investment. Journal of General Management, 28, 4, 15-36.

Orlov, S., Rovenskaya, E., Puaschunder, J.M. \& Semmler, W. (work in progress). Bonds stabilizing climate: A DICE model approach.

Puaschunder, J. M. (2010). On Corporate and Financial Social Responsibility. Unpublished Doctoral Thesis. University of Vienna, Faculty of Psychology.

Puaschunder, J. M. (2011). Intergenerational equity as a natural behavioral law. United States Copyright Office record TXu1-743-422. Library of Congress of the United States. Washington, D.C., USA.

Puaschunder, J.M. (2013). Ethical investing and socially responsible investing. In Baker K. H. \&

Ricciardi, V. (Eds.). Investor Behavior. New York: John Wiley \& Sons Finance Series.

Puaschunder, J.M. (2015a). On eternal equity in the fin-de-millénaire. Journal of Leadership, Accountability and Ethics, 13, 2, 1-24.

Puaschunder, J. M. (2015b). On the social representations of intergenerational equity. Oxford Journal of Finance and Risk Perspectives, 4, 4, 78-99.

Puaschunder, J. (2015c). When investors care about politics: A meta-synthesis of political divestiture studies on the capital flight from South Africa during Apartheid. Business, Peace and Sustainable Development, 5, 24, $29-52$.

Puaschunder, J. M. (2016a). Intergenerational climate change burden sharing: An economics of climate stability research agenda proposal. Global Journal of Management and Business Research: Economics and Commerce, 16, 3, 31-38.

Puaschunder, J.M. (2016b). Mapping Climate Justice. Proceedings of the 2016 Young Scientists Summer Program Conference, International Institute for Applied Systems Analysis (IIASA), Laxenburg, Austria. 
Puaschunder, J. M. (2016c). Socially Responsible Investment as emergent risk prevention and means to imbue trust in the post-2008/2009 world financial crisis economy. In: O. Lehner (Ed.), Routledge Handbook of Social and Sustainable Finance, pp. 222-238, London: Taylor \& Francis.

Puaschunder, J.M. (2016d). The call for global responsible inter-generational leadership: The quest of an integration of inter-generational equity in corporate social responsibility (CSR) models. In D. Jamali (Ed.). Comparative Perspectives on Global Corporate Social Responsibility, pp. 276-289. Hershey: IGI Global Advances in Business Strategy and Competitive Advantage Book Series. doi: 10.4018/978-1-5225-0720-8.ch014

Puaschunder, J. M. (2016e). The role of political divestiture for sustainable development. Journal of Management and Sustainability, 6, 1, 76-91.

Puaschunder, J.M. (2017a). Climate in the 21st century: A macroeconomic model of fair global warming benefits distribution to grant climate justice around the world and over time. Retrievable at https://papers.ssrn.com/sol3/papers.cfm?abstract_id=2964385

Puaschunder, J. M. (2017b). Cross-Sectoral Solution-Finding and Policy Dialogue on Information and Communication Technologies for Sustainable Development. In M. Gudic, T. K. Tan and P. M. Flynn, Beyond the Bottom Line: Integrating the UN Global Compact into Management Practices, pp. 32-46. New York, NY: Greenleaf Publishing.

Puaschunder, J.M. (2017c). Socio-psychological motives of socially responsible investors. Advances in Financial Economics, 19, 1, 209-247.

Puaschunder, J.M. (2017d). Sunny side up! From climate change burden sharing to fair global warming benefits distribution: Groundwork on the metaphysics of the gains of global warming and the climatorial imperative. Proceedings of the Administrative Sciences Association of Canada Annual Conference, HEC Montreal, Quebec, Canada.

Puaschunder, J.M. (2017e). The call for global responsible inter-generational leadership: The quest of an integration of inter-generational equity in corporate social responsibility (CSR) models. Natural Resources Management: Concepts, Methodologies, Tools, and Applications. Information Resources Management Association. Hershey: IGI Global.

Puaschunder, J.M. (forthcoming a). Ethical decision making under social uncertainty: An introduction of Überethicality. Sustainable Production and Consumption.

Puaschunder, J. M. (forthcoming b). Nachhaltigkeit und Investment. In: Bamberg \& Schmitt, Psychologie und Nachhaltigkeit: Konzeptionelle Grundlagen, Anwendungsbeispiele und Zukunftsperspektiven.

Puaschunder, J.M. \& Schwarz, G. (2012). The future is now: How joint decision making curbs hyperbolic discounting but blurs social responsibility in the intergenerational equity public policy domain. Harvard University Situationist Law and Mind Sciences Working Paper.

Reinhardt, F. L., Stavins, R. N. \& Vietor, R. H. (2008). Corporate social responsibility through an economic lense. Review of Environmental Economics and Policy, 2, 2, 219-239.

Renneboog, L. D. R., Horst, J. R. T. \& Zhang, C. (2007). Socially responsible investments: Methodology, risk and performance. Tilburg University Center for Economic Research Discussion Paper 2007-2031, Tilburg, The Netherlands.

Rosen, B. N., Sandler, D. M. \& Shani, D. (1991). Social issues and socially responsibility investment behavior: Preliminary empirical investigation. Journal of Consumer Affairs, 25, 2, 221-234.

Sachs, J.D. (2014). Climate Change and Intergenerational Well-Being, in: Bernard, L., Semmler, W. (Eds.), The Oxford Handbook of the Macroeconomics of Global Warming. Oxford University Press.

Schueth, S. (2003). Socially responsible investing in the United States. Journal of Business Ethics, 43, $189-194$.

Social Investment Forum Report (2006). Report on socially responsible investing trends in the United States. Social Investment Forum Industry Research Program 10-year review, January 24, 2006.

Solomon, J. F., Solomon, A. \& Norton, S. D. (2002), Socially responsible investment in the UK: Drivers and current issues. Journal of General Management, 27, 3, 1-13.

Soros, G. (2008). The new paradigm for financial markets: The credit crisis of 2008 and what it means. New York: Public Affairs.

Sparkes, R. (2002). Socially responsible investment: A global revolution. Cronwall: Wiley. 
Sparkes, R. \& Cowton, Ch. J. (2004). The maturing of socially responsible investment: A review of the developing link with corporate social responsibility. Journal of Business Ethics, 52, 45-57.

Steurer, R. (2010). The role of governments in corporate social responsibility: Characterising public policies on CSR in Europe. Policy Science, 43, 49-72.

The Global Social Crisis: Report on the World Social Situation 2011. New York: United Nations.

Voorhes, M. (1999). The US divestment movement: How sanctions work: Lessons from South Africa. New York: St. Martin's.

Williams, G. (2005). Are socially responsible investors different from conventional investors? A comparison across six countries. Unpublished working paper, University of Bath.

Wolff, M. (2002). Response to “Confronting the critics.” New Academy Review, 1, 230-237.

World Bank (2015). Green bonds attract private sector climate finance, World Bank Brief, 2015.

The World Economic Forum 2015 Report. Davos, Switzerland: World Economic Forum.

World Development Report (2015). Mind, society and behavior. Washington D.C.: World Bank. 